\title{
Efficiency of using agricultural land in the context of natural and economic zones of the Krasnodar Kari in order to involve them into circulation
}

\author{
Yanina Zaitseva ${ }^{1}{ }^{*}$ and Nikolay Radchevsky ${ }^{1}$ \\ ${ }^{1}$ Kuban GAU, 13, Kalinina str., 350044, Krasnodar, Russia
}

\begin{abstract}
The efficiency of using agricultural land in the context of natural and economic zones of the Krasnodar Krai in order to involve them into circulation is studied in this paper. It is analyzed that the productive properties of the land directly depend on the fertility of the soil, which is characterized by soil types, humus reserves, mechanical composition and other indicators. Soil fertility was assessed, the indicator of which is the bonitet score.
\end{abstract}

\section{Introduction}

The Krasnodar Krai is famous for its fertile lands, but it must be remembered that the lands of the municipalities of the Kraisomehow differ in quality. Consequently, the efficiency of agricultural production in individual regions will differ from each other.

In order to determine the efficiency of the use of agricultural land by municipalities of the Krasnodar Krai, taking into account the productive properties of land in the context of natural and economic zones, we will find, for a start, the average soil score for each municipal formation in the context of agricultural zones. There are six such zones in the region: Northern, Central, Western, Anapo-Taman, South-Piedmont, and Black Sea.

\section{Materials and methods}

From the materials of the assessment of the lands of the Krasnodar Krai (initial indicators of soil fertility) in 1990, we write down the soil scores of dry arableland and irrigated arableland in Table 1 by municipalities and group them by zones [1].

\footnotetext{
*Corresponding author: yaninazaiceva@mail.ru
} 
Table 1. Scores of bonitet of arable land by municipalities of Krasnodar Krai by zones.

\begin{tabular}{|c|c|c|}
\hline \multirow{2}{*}{ Municipalities } & \multicolumn{2}{|c|}{ Bonitet scores } \\
\hline & dry arable land & irrigated arable land \\
\hline \multicolumn{3}{|c|}{ Northern zone } \\
\hline Beloglinsky & 72 & - \\
\hline Yeysky & 76 & - \\
\hline Kanevsky & 79 & 80 \\
\hline Krylovsky & 75 & 72 \\
\hline Kushchevsky & 75 & - \\
\hline Leningradsky & 80 & 78 \\
\hline Novopokrovsky & 76 & 81 \\
\hline Pavlovsky & 80 & 79 \\
\hline Starominskiy & 74 & 74 \\
\hline Tikhoretsky & 81 & 80 \\
\hline Shcherbinovsky & 73 & 74 \\
\hline \multicolumn{3}{|c|}{ Central zone } \\
\hline Bryukhovetsky & 83 & 83 \\
\hline Vyselkovsky & 84 & 84 \\
\hline Gulkevichesky & 83 & 68 \\
\hline Dinskoy & 81 & 81 \\
\hline Kavkazsky & 82 & 82 \\
\hline Korenovsky & 85 & 85 \\
\hline Kurganinsky & 83 & 67 \\
\hline Novokubansky & 82 & 65 \\
\hline Primorsko-Akhtarsky & 82 & 78 \\
\hline Tbilissky & 79 & 75 \\
\hline Timashevsky & 84 & 85 \\
\hline Ust-Labinsky & 81 & 77 \\
\hline Armavir & 77 & 74 \\
\hline Krasnodar & 78 & 75 \\
\hline \multicolumn{3}{|c|}{ Western zone } \\
\hline Kalininsky & 78 & 66 \\
\hline Krasnoarmeyskiy & 66 & 57 \\
\hline Slavyansky & 49 & 39 \\
\hline \multicolumn{3}{|c|}{ Anapo - Taman zone } \\
\hline Temryuksy & 47 & 29 \\
\hline Anapa & 56 & 40 \\
\hline \multicolumn{3}{|c|}{ South-Piedmont zone } \\
\hline Abinsky & 58 & 51 \\
\hline Absheronksy & 48 & 54 \\
\hline Belorechensky & 61 & 59 \\
\hline Crimean & 57 & 40 \\
\hline Labinsky & 82 & 65 \\
\hline Mostovsky & 66 & 56 \\
\hline Otradnensky & 83 & - \\
\hline Seversky & 54 & 53 \\
\hline Uspensky & 74 & 75 \\
\hline GoryachyKlyuch & 52 & 50 \\
\hline \multicolumn{3}{|c|}{ Black Sea zone } \\
\hline Tuapsinsky & 51 & 47 \\
\hline Gelendzhik & 46 & 46 \\
\hline Novorossiysk & 58 & 59 \\
\hline Sochi & 42 & 45 \\
\hline
\end{tabular}


From table 1, it can be noted that the soil score of dry and irrigated arable land differs among themselves depending on the municipality, with the exception of Bryukhovetsky, Vyselkovsky, Dinsky, Kavkazsky, Korenovsky, which are located in the Central zone, and Starominsky district, as well as the city of Gelendzhik. In these municipalities, the soil score of dry and irrigated arable land is the same. In such areas as: Beloglinsky, Yeysky, Kushchevsvsky and Otradnensky, there is no irrigated arable land, these areas are included in the Northern zone of the region.

In the report on the availability and distribution of lands in the Krasnodar Krai, we took information on the area of all arable land and the area of irrigatedarable land. The area of dryarable landwas found as the difference between the area of all arable land and the area of irrigatedarable land [2].

All data on municipalities and areas by zones are shown in Table 2.

Table 2. Information on arable land areas by municipalities of the Krasnodar Krai by zones, hectares.

\begin{tabular}{|c|c|c|c|}
\hline Municipalities & $\begin{array}{c}\text { Stotal arable } \\
\text { land }\end{array}$ & $\begin{array}{c}S \text { irrigated } \\
\text { arable land }\end{array}$ & Sdry arable land \\
\hline \multicolumn{4}{|c|}{ Northern zone } \\
\hline Beloglinsky & 128308 & - & 128308 \\
\hline Yeysky & 143691 & - & 143691 \\
\hline Kanevsky & 177018 & 7086 & 169932 \\
\hline Krylovsky & 114587 & 1397 & 113190 \\
\hline Kushchevsky & 197930 & - & 197930 \\
\hline Leningradsky & 109803 & 5127 & 104676 \\
\hline Novopokrovsky & 179209 & 8526 & 170683 \\
\hline Pavlovsky & 146676 & 3682 & 142994 \\
\hline Starominskiy & 80877 & 1170 & 79707 \\
\hline Tikhoretsky & 140348 & 7105 & 133243 \\
\hline Shcherbinovsky & 105448 & 931 & 104517 \\
\hline \multicolumn{4}{|c|}{ Central zone } \\
\hline Bryukhovetsky & 102057 & 5650 & 96407 \\
\hline Vyselkovsky & 140913 & 5359 & 135554 \\
\hline Gulkevichesky & 100995 & 6175 & 94820 \\
\hline Dinskoy & 83188 & 14775 & 68413 \\
\hline Kavkazsky & 89870 & 9130 & 80740 \\
\hline Korenovsky & 113038 & 6323 & 106715 \\
\hline Kurganinsky & 111599 & 9737 & 101862 \\
\hline Novokubansky & 138428 & 2832 & 135596 \\
\hline $\begin{array}{l}\text { Primorsko- } \\
\text { Akhtarsky }\end{array}$ & 78229 & 4808 & 73421 \\
\hline Tbilissky & 108834 & 12098 & 96736 \\
\hline Timashevsky & 116564 & 5909 & 110655 \\
\hline Ust-Labinsky & 15207 & 2641 & 12566 \\
\hline Armavir & 40927 & 12944 & 27983 \\
\hline Krasnodar & 40927 & 12944 & 27983 \\
\hline \multicolumn{4}{|l|}{ Western zone } \\
\hline Kalininsky & 96215 & 34309 & 61906 \\
\hline Krasnoarmeyskiy & 129837 & 89741 & 40096 \\
\hline Slavyansky & 109103 & 82467 & 26636 \\
\hline \multicolumn{4}{|c|}{ Anapo - Taman zone } \\
\hline Temryuksy & 55017 & 14476 & 40541 \\
\hline Anapa & 31986 & 2611 & 29375 \\
\hline \multicolumn{4}{|c|}{ South-Piedmont zone } \\
\hline Abinsky & 52162 & 27653 & 24509 \\
\hline Absheronksy & 7188 & 465 & 6723 \\
\hline
\end{tabular}




\begin{tabular}{|l|c|c|c|}
\hline Belorechensky & 62008 & 8310 & 53698 \\
\hline Crimean & 61747 & 24879 & 36868 \\
\hline Labinsky & 100091 & 2096 & 97995 \\
\hline Mostovsky & 50638 & 373 & 50265 \\
\hline Otradnensky & 99301 & - & 99301 \\
\hline Seversky & 49071 & 9817 & 39254 \\
\hline Uspensky & 54052 & 744 & 53308 \\
\hline GoryachyKlyuch & 2111 & 678 & 20433 \\
\hline \multicolumn{4}{|c|}{ Black Sea zone } \\
\hline Tuapsinsky & 1247 & 54 & 1193 \\
\hline Gelendzhik & 90 & 88 & 2 \\
\hline Novorossiysk & 9073 & 1156 & 7917 \\
\hline Sochi & 3468 & 1063 & 2405 \\
\hline
\end{tabular}

From the information given in Tables 1 and 2, we find the average bonitet of arable land in the municipalities of the region in the context of zones according to formula 1 :

$$
\mathrm{B}_{\mathrm{av}}=\frac{\mathrm{B}_{\mathrm{dry}} * \mathrm{~S}_{\mathrm{dry}}+\mathrm{B}_{\mathrm{irr}} * \mathrm{~S}_{\mathrm{irr}}}{\mathrm{S}_{\text {total arable land }}},
$$

where $B_{d r y}-$ dry arable land soil score;

$\mathrm{S}_{\mathrm{d} r y}-$ dry arable land area, ha;

$B_{\text {irr }}$ - soil score of irrigated arable land;

$\mathrm{S}_{\mathrm{i} r r}$ - irrigatedarable land area, ha;

$\mathrm{S}_{\text {total }}$ - total arable land area, ha.

Let's calculate the average bonitet scores of arable land for all municipalities of the Krasnodar Krai according to formula 1 and group them by zones. Let'swrite the obtained results in Table 3.

Table 3. Average scores of bonitet of arable land by municipalities of the Krasnodar Krai by zones.

\begin{tabular}{|c|c|}
\hline Municipalities & Scores \\
\hline \multicolumn{2}{|c|}{ Northern zone } \\
\hline Beloglinsky & 72 \\
\hline Yeysky & 76 \\
\hline Kanevsky & 79 \\
\hline Krylovsky & 75 \\
\hline Kushchevsky & 75 \\
\hline Leningradsky & 80 \\
\hline Novopokrovsky & 76 \\
\hline Pavlovsky & 80 \\
\hline Starominskiy & 74 \\
\hline Tikhoretsky & 81 \\
\hline Shcherbinovsky & 73 \\
\hline \multicolumn{2}{|c|}{ Central zone } \\
\hline Bryukhovetsky & 83 \\
\hline Vyselkovsky & 84 \\
\hline Gulkevichesky & 82 \\
\hline Dinskoy & 81 \\
\hline Kavkazsky & 82 \\
\hline Korenovsky & 85 \\
\hline Kurganinsky & 82 \\
\hline Novokubansky & 82 \\
\hline Primorsko-Akhtarsky & 82 \\
\hline Tbilissky & 79 \\
\hline
\end{tabular}




\begin{tabular}{|c|c|}
\hline Timashevsky & 84 \\
\hline Ust-Labinsky & 81 \\
\hline Armavir & 76 \\
\hline Krasnodar & 77 \\
\hline \multicolumn{2}{|c|}{ Western zone } \\
\hline Kalininsky & 74 \\
\hline Krasnoarmeyskiy & 60 \\
\hline Slavyansky & 41 \\
\hline \multicolumn{2}{|c|}{ Anapo - Taman zone } \\
\hline Temryuksy & 42 \\
\hline Anapa & 55 \\
\hline \multicolumn{2}{|c|}{ South-Piedmont zone } \\
\hline Abinsky & 54 \\
\hline Absheronksy & 48 \\
\hline Belorechensky & 60 \\
\hline Crimean & 50 \\
\hline Labinsky & 82 \\
\hline Mostovsky & 66 \\
\hline Otradnensky & 83 \\
\hline Seversky & 54 \\
\hline Uspensky & 74 \\
\hline GoryachyKlyuch & 52 \\
\hline \multicolumn{2}{|c|}{ Black Sea zone } \\
\hline Tuapsinsky & 51 \\
\hline Gelendzhik & 46 \\
\hline Novorossiysk & 58 \\
\hline Sochi & 43 \\
\hline
\end{tabular}

\section{Results}

As a result of our survey, the most fertile regions were: Bryukhovetsky, Vyselkovsky, Gulkevichesky, Kavkazsky, Korenovsky, Kurganinsky, Labinsky, Leningradsky, Novokubansky, Otradnensky, Primorsko-Akhtarsky, Pavlovsky, Timashevsky, Tikhoretsky and Ust-Labinsky. Their soil score was above 80. All these areas are located in the Central and Northern zones of the region.

Less fertile areas and cities with a bonitet score less than 55 are: Apsheronsky, Crimean, Seversky, Slavyansky, and Temryuksky; the city of Anapa, Gelendzhik, GoryachyKlyuch, and Sochi.

\section{Conclusions}

The above data in the tables clearly show that the assessment scores for the municipalities of the region are quite high. Therefore, this allows concluding about the fertility of the land.

In our opinion, it is imperative to take into account the fertility of agricultural land in the Krasnodar Krai, since this will give an impetus to the functioning and development of the agricultural land market and, accordingly, the country's economy as a whole.

\section{References}

1. Ya.V. Zaitseva, Economy and entrepreneurship 3(116), 400-402 (2020) 
2. Ya.V. Zaitseva, Modern problems and prospects for the development of land and property relations. Collection of papers based on the materials of the All-Russian scientific and practical conference (2019)

3. Ya.V. Zaitseva, Scientific support of the agro-industrial complex. Collection of abstracts based on the materials of the All-Russian (national conference) (Krasnodar, 2019)

4. Ya.V. Zaitseva, Investment management and state investment policy-2. Material of the international scientific conference 2(91), 753-757 (2018)

5. Ya.V. Zaitseva, Creativity of young scientists and students in the field of economic sciences. Material of the international complex of scientific publications of youth, 100106 (Krasnodar, 2018)

6. Ya.V. Zaitseva, Economy and entrepreneurship 2(91), 753-757 (2018)

7. Ya.V. Zaitseva, Economy and entrepreneurship 12-1(89), 345-347 (2017)

8. K.I. Mikov, Ya. . Zaitseva, Modern problems and prospects for the development of land and property relations. Collection of papers based on the materials of the II AllRussian scientific and practical conference, 452-454 (Krasnodar, 2020)

9. N.M. Radchevsky, Z.R. Sheudzhen, Ya.V. Zaitseva, State registration and accounting of real estate: a tutorial (KubGAU, Krasnodar, 2020)

10. N.M. Radchevsky, Ya.V. Zaitseva, Economy and entrepreneurship 12(113), 122-125 (2019)

11. N.M. Radchevsky, Ya.V. Zaitseva, Economy and entrepreneurship 11(112), 1079-1081 (2019)

12. Ya. Zaitseva, E3S Web of Conferences 244, 03017 https://doi.org/10.1051/e3sconf/202124403017

13. E. Tsoraeva, A. Bekmurzov, S. Kozyrev, A. Khoziev, A. Kozyrev, E3S Web of Conferences 215, 02003 (2020) https://doi.org/10.1051/e3sconf/202021502003

14. E. Tsoraeva, S. Mezhyan, M. Kataeva, L. Hugaeva, T. Rogova, E3S Web of Conferences 224, 03001 (2020) https://doi.org/10.1051/e3sconf/202022403001

15. B. Kozyrev, E. Tsoraeva, Al-Azawi Nagam, A. Chibirova, A. Kozyrev, E3S Web of Conferences 244, 03018 (2021) https://doi.org/10.1051/e3sconf/202124403018

16. V.D. Zhukov, E.N. Tsoraeva, A.U. Perov, IOP Conf. Series: Earth and Environmental Science 650, 012028 (2021) https://doi:10.1088/1755-1315/650/1/012028

17. E.N. Tsoraeva, R.K. Gadzhiev, S.E. Kuchiev, A.A. Pekh, S.A. Mezhyan, IOP Conf. Series: Materials Science and Engineering 1083, 012052 (2021) https://doi:10.1088/1757-899X/1083/1/012052 